\title{
Panobinostat/Bortezomib/Dexamethasone Regimen
}

National Cancer Institute

\section{Source}

National Cancer Institute. Panobinostat/Bortezomib/Dexamethasone Regimen. NCI

Thesaurus. Code C136275.

A chemotherapy regimen consisting of panobinostat, bortezomib and dexamethasone that is used for the treatment of plasma cell myeloma. 